\title{
Weighing Up Contextual and Personal Factors in Selecting Grammar Teaching Approaches: A Case Study from Indonesia
}

\author{
I.G.A. Lokita Purnamika Utami ${ }^{1 *}$ \\ ${ }^{1}$ Universitas Pendidikan Ganesha \\ *Corresponding author. Email: lokitapurnamika@undiksha.ac.id
}

\begin{abstract}
It is widely accepted that EFL teachers may teach grammar through deductive or inductive approaches or a combination of both. In Indonesian context, despite the emphasis of communicative purpose of learning English demanded by the curriculum, the trend of using deductive approach in teaching grammar is more apparent than inductive approach. Little is known about what factors affecting this decision. This case study aims to reveal factors affecting teachers' decision in implementing grammar teaching approaches. The study was conducted in a public junior high school in Indonesia whose English teachers were dominantly in favor with the use of deductive approach. The participants were 4 English teachers. The data were collected through document analysis, non-participant observation and developmental interview. The study indicates that there are two factors affecting their grammar teaching approach, namely contextual and personal factors. However, teacher decision can be re-adjusted and affected more by contextual factor, especially student readiness and level of grammar difficulty, than by personal factor. The study also reveals the compliance to the grammar teaching approach as demanded by the curriculum in teacher showcase does not necessarily reflect their daily practices. Implication on increasing awareness raising on current 21 st century learning paradigm and school support for professional development engagement is mentioned.
\end{abstract}

\section{Keywords: Contextual factor, Personal factor, Grammar teaching, Deductive approach, Inductive} approach.

\section{INTRODUCTION}

To have a proficient English, EFL learners must have capability to enhance and practice what essential in English learning such as vocabulary, grammar and four language skills. According to Grass and Coppen [1], grammar becomes the main thing to learn by English language learners. It is, furthermore, essential as it is "too important to be ignored, and that without a good knowledge of grammar, learners' language development will be severely constrained" [2] Moreover, Richards and Renandya [3] mentions that grammatical competence is after all communicative competence because it provides the basis for communicative competence in writing, speaking, reading, and listening. Thus, the importance of grammar cannot be denied in language learning by both teachers and students.

Grammar can be taught through two main approaches: deductive and inductive approaches. Some teachers apply one of these or creatively combine them. A deductive approach is when the rule is presented explicitly and the language is produced based on the rule. Meanwhile inductive approach is when sample of language is presented to generate an intuitive understanding of the rule [4]. Deductive approach is more teachers centered meanwhile inductive approach allows more space for students to contribute in their learning.

Krashen's theory of language acquisition has enlightened language learning instruction by distinguishing 'acquired system' and 'learned system'. The acquired system refers to the subconscious process of learning which concentrated not in the form of the utterances but mostly about communicative interaction. While the learned system is referred to the formal instruction which producing conscious knowledge. In relation to teaching grammar, Decoo [5] states that inductive approach evokes natural language learning that is "easily identified with acquisition". Thus, in teaching grammar, teachers may emphasis on 'acquired system' process of learning 
through inductive approach or emphasis on learned system through deductive approach. Some view that acquired system is more significant than learned system in language learning.

Question on how to teach grammar has led to a debatable discussion. There was enormous amount of research which have exposed the effectiveness of inductive approach in teaching grammar [6, 7]. Meanwhile, there were many claims that deductive approach is more effective [8, 10]. A combination of both approaches in teaching grammar is also an option [11].

The decision on which teaching grammar is appropriate depends largely on the purpose of teaching English. In the context of communicative purpose of teaching English, deductive approach in teaching grammar seems less appropriate since it focuses more on 'form' rather than on 'meaning'. Negahdaripour and Amirghassemi [12] claim that deductive approach is more potential to enhance learners' accuracy rather than fluency. Therefore, to enhance students' fluency English teachers need to accommodate grammar teaching in a more communicative way or implicitly instead of through explicit teaching as in deductive approach.

Drawing from this understanding, it is interesting to note that in Indonesian context, there is a trend to use deductive approach for teaching grammar despite its communicative learning purpose [13]. English in Indonesia is seen as an international language, thus, English is learnt for instrumental reason such as to get a job, to be involved in business and to establish

\section{LITERATURE REVIEW}

\subsection{Deductive and inductive approach to grammar teaching}

Language Acquisition Device is proposed by Chomsky. Chomsky states that LAD is a hypothetical device that helps language learners to learn and understand language. The formulation of the model can be drawn as follows [16];

Figure 1. Formulation of LAD

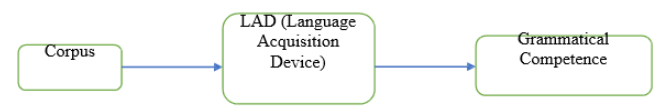

This formulation describes how language acquisition is started with the corpus of speech that passes through LAD and ended with an outcome of grammatical competence. This formula brings an implication to language learning that children in the early stages of learning language structure should be taught without the use of transformation but international network which requires communicative ability [14]. Ideally, to reflect on this purpose, grammar teaching need to be done through inductive approach which allow more space for meaning focused. However, research in Indonesian context shows that English teachers prefers to teach grammar deductively by explaining rules and expecting students to generate sentences based on the taught rules. Hartoyo [15] assumed that this trend is motivated by the condition of lack of English exposure in Indonesia, thus "grammar in translation rather than language function is still perceived as very important in Indonesia'. Furthermore, Arifin [10] mentions that many Indonesian English teachers only explain the rules and patterns of the tenses without providing sufficient exposure to the language and review to the lesson because of limited time allotment for English lesson. This practice seems contradict the communicative teaching purpose as students has to memorize rules instead of focusing on meaning.

Research in relation to grammar teaching in Indonesian context is largely on comparing between deductive and inductive approach. In a wider context, grammar teaching research focus on the effectiveness of approaches, teachers and students perception [6, 7]. However little is known about the factors affecting teachers' decision on grammar teaching approach they choose. Deriving from the narration, this research attempted to know some factors affecting Indonesian English teachers' decision on applying grammar teaching approaches.

emphasizing more on the basic grammatical relation to the context in universal (communicative framework). In relation to grammar teaching, the formulation of LAD describes the inductive approach which concerns on the example of the sentence to find out the rules of the grammatical rather than the form. In applying inductive approach teacher gives example of sentences to the students and allow them to construct the rule of the language by themselves. In other words, inductive approach involves the learners recognizing patterns and working out a 'rule' for themselves before they use the language.

\subsection{The effectiveness of deductive and inductive approach}

Grammar is known to be a difficult subject to learn, especially grammar of a foreign language. Studies on grammar difficulties has shown varied findings. A study about EFL teachers' and learners' perception of grammatical difficulties in Aljouf 
University revealed some difficulties in English grammar structures [17]. Moreover, this study also found some similarities and differences in the supposition of the grammars acquisition based on different reason and factors such as L1 Knowledge and transmission, language proficiency, complexity of grammar, and poor quality of textbook. In addition, teachers' preference of grammar teaching approaches is also in the equation. Polat [18] conducted a research about teachers' attitude toward teaching English grammar in Eskisehir and Kutahya. The result shows most of the participants $(89 \%)$ believe that grammar should be taught with explicit rules or deductively. They believed that the explicit grammar (indirect) is much better in teaching grammar. [19] also conducted a study about teachers' belief in English grammar teaching approach. The result of this study revealed that teacher with higher proficiency prefer to use indirect approach (inductive). They believe that indirect grammar teaching as the best instruction to increase learners' grammar achievement and proficiency. Yet, they mostly implementing the direct grammar teaching in the classroom. This study provides evidence of contradiction between what teachers believe and what they do in the classroom. Furthermore, study on grammar approach preferences needs to be supported with studies contrasting the effect of both approaches.

There are many studies concern on contrasting deductive and inductive approach to teach grammar. Gorat and Prijambodo [20] examined the effect of using deductive and inductive approach in teaching English grammar. This study revealed that there is a significant effect of the use of inductive approach in teaching English grammar. However, for low ability students, inductive approach was perceived to be more challenging than deductive approach. The result of their study s also supported by Al-Zu'bi [21] who found that inductive approach has a positive impact to students' grammar achievement. The study highlights the need for teachers to utilize more creative instruction design to motivate students learning. Another study by Sharandeep and Niwas [22] also revealed the same finding in the context of grammar teaching at elementary level. The study utilized a pretest and post-test to measure learners grammar ability. In pre-test, the result of the test was homogenous for both inductive and deductive approach. However, in the post test the result revealed that the mean score was higher on inductive approach than deductive approach.
Although, several studies have revealed the effectiveness of using inductive approach, Sik [23] discovered that teachers are more comfortable teaching grammar by using deductive approach. Besides, his study also found that in terms of achievement, data showed that there is no significant different of grammar achievement when students were taught by deductive or inductive approach. As if to support this finding, Negahdaripour and Amirghassemi [12] found that deductive approach was more effective to increase learners' oral accuracy. Their study concludes that deductive approach was more potential to be emphasized on the accuracy rather than fluency.

Debate on which approach to use is endless. However, there are some studies suggest the use of combination of these approaches. For instance, study of innovative strategy for teaching tenses for adult learners introduces a combination of these two approaches [11]. They followed 5 steps in integrating the deductive and inductive approach. The result displays that the combination of those approach can be used for deep understanding on the grammar's rules and usage. Moreover, Toprak [24] also discover teachers' belief in the use of inductive approach combined with communicative approach in teaching grammar. He also found that teachers belief and performance are affected by contextual and personal factor

Although there are many studies about the two approach preferences and effectiveness, little attention is given to factors affecting their preference. This study emphasized on looking at teachers' perception on inductive grammar teaching. What makes this study different is the perceptions being investigated was studied from teachers who practice deductive grammar teaching as their routine. Findings of this study may lead us to understand factors, motive and contextual challenges that affect teachers to not choosing inductive approach in their grammar teaching.

\section{METHOD}

This research was a qualitative research with casestudy research design. The research was conducted in a local secondary school in Indonesia to exemplify a case of grammar approach preferences. This school employed 4 English teachers who mostly teaching through deductive approach. The subjects or participants were all the four English teachers who are teaching seventh to ninth grades. Table 1 presents the demographic information of each participant. 
Table 1. Participants demographic information

\begin{tabular}{|c|c|c|c|}
\hline \multirow{2}{*}{ Subject } & Length of Career & \multicolumn{2}{|l|}{ Professionalism status } \\
\cline { 3 - 4 } & & Yes & No \\
\hline A & 5 Years & $\square$ & - \\
\hline B & 17 Years & $\square$ & - \\
\hline C & 26 years & $\square$ & - \\
\hline D & 30 years & $\square$ & - \\
\hline
\end{tabular}

To collect data researcher did document analysis, non-participant observation and developmental interview for each teacher. Document analysis was done to check the participants' teaching documents (lesson plans, material presentation and media). Grammar teaching indicators proposed by Grauss and Coppen [1] were used to analyze these documents. The indicators to determine deductive approach namely 1) teaching rules in the beginning activity, 2) exemplifying rules, 3) focusing on explaining rules, 4) explaining rules and 5) teaching with teacher-centered. Furthermore, the indicators used to determine the inductive approach are 1) searching for a rule, 2) Using examples from which to extract a rule, 3) Inducing learners to infer rules themselves, 4) guiding learners to search for rules, and 5) more studentcentered. Besides document Analysis, non-participant observation was conducted twice for each teachers. The researcher was a non-participant observer who stayed uninvolved but present at the classroom [25]. To do this, an observation sheet was developed reflecting grammar teaching indicators proposed by
Grauss and Coppen [1]. Moreover, to collect data the study also administered developmental interview. This interview protocol is flexible in nature which is less formal and open ended with a list of desired questions [26]. An interview guidance was developed to reflect three dimensions that determine perception, i.e. perceiver, target and situation, proposed by Robins and Judges [27]. Although an interview guide was prepared but it is not an absolute contract; thus, it does not limit the way interview developed. Researcher may add or modify questions based on the response given to support the depth and breadth of participants profiling. The interviews were recorded, transcribed verbatim and analyzed. Data were analyzed qualitatively by using Interactively Data Analysis Model by Miles and Hubberman [28] involving three steps: 1) data reduction (selecting, concentrating, simplifying, abstracting, and transforming necessary field note transcription), 2) data display (compressing and importing obtained data into transcript), and 3) conclusion drawing.

\section{RESULT AND DISSCUSSION}

The result of document analysis and non-

participant observation is presented in Table 2.

Table 2. Result of document analysis and observation

\begin{tabular}{ccccc}
\hline $\begin{array}{c}\text { Teachers code- } \\
\text { length of teaching }\end{array}$ & $\begin{array}{c}\text { Document } \\
\text { checking }\end{array}$ & Observation 1 & Observatio & Category \\
\hline A-5 years & Inductive & Inductive & Inductive & $\begin{array}{c}\text { Inductive } \\
\text { teacher }\end{array}$ \\
\hline B-17 years & Inductive & Deductive & Deductive & $\begin{array}{c}\text { Deductive } \\
\text { teacher }\end{array}$ \\
\hline C- 26 years & Deductive & Deductive & Deductive & $\begin{array}{c}\text { Deductive } \\
\text { teacher }\end{array}$ \\
\hline D-30 years & Inductive & Deductive & Deductive & $\begin{array}{c}\text { Deductive } \\
\text { teacher }\end{array}$ \\
\hline
\end{tabular}


From table 2, we see that teacher were categorized into two: deductive teacher (teacher A) and inductive teachers (teacher B, C and D). The table also shows discrepancy between the results of document analysis and teaching practice observation. Based on teaching documents, analysis it was found that most teachers seem to conduct inductive approach. This finding contradicted what was found during teaching practice observation, that most teachers taught grammar deductively. The interview revealed that this interesting discrepancy was motivated by teachers' compliance to educational policy, i.e., what curriculum demands. Curriculum demands English to be taught communicatively through focusing on meaning not on form [10]. Thus, grammar teaching needs to be integrated in teaching language function or in reading text discussion. Utami and Prestridge [29] viewed that teachers are inclined to have two different disposition to respond to educational policy. They may act following compliant disposition or indifferent disposition. This view explains why teacher B's and D's teaching documents different from their practices; meanwhile teacher $\mathrm{A}$ and $\mathrm{C}$ maintain similar orientation. It can be understood that the first two teachers' action was an example of compliant disposition to the policy. They developed teaching documents to fulfill the policy demands. Meanwhile, the latter teachers' action followed the indifferent disposition.

Table 2, also presents another interesting findings. It shows that the most junior teacher was the only one that applied inductive approach in his practice. Although this cannot be inferred as a pattern of connection between the level of experience and grammar teaching choice, this finding is necessary to note. In a contrast to this finding, Sik [23] concluded that teachers, no matter experienced or not, prefer deductive approach as they perceived the inductive way as much more vulnerable in grammar teaching.

Based on the interview there are 2 major factors affecting teachers' decision in applying grammar teaching approach. These factors are personal factor and contextual factor. Personal factors include attitude, interest, motive, experience/knowledge, and expectation. Meanwhile, contextual factor include student readiness, peers readiness, level of grammar difficulty, curriculum demand, and student feeling.

\subsection{Personal Factors: What I think, What I like, What I know and What I am}

Teaching attitude. Teachers' attitude about teaching approaches is varied. Teacher A had a current teaching paradigm adjustment attitude. He perceived deductive approach as "too old-fashioned or traditional" and "not suitable" with current teaching paradigm which demands critical thinking exercise. $\mathrm{He}$ wanted to introduce grammar through student active engagement in discovering the rules. Other teachers $(B, C, D)$ had a more technical orientation attitude. They admitted that deductive approach is a traditional method but as stated by teacher B “...The deductive method has a simple activity and does not requires much time" These teacher favored the simplicity of deductive approach which facilitates immediate grasp and is less time-consuming. In Indonesian secondary classroom, time allotment for learning English is limited, teacher $\mathrm{C}$ mentioned that "...it is necessary to explain the patterns directly for students. Then, students can have more practice in making their own sentences based on the taught pattern". These teachers don't want to spend too much time on grammar as they have other things to cover in one semester.

\subsubsection{Interest}

Teachers are interested to do different things in their classes which partly motivated by students' characteristics, the environment and the level of material difficulty. Teacher A liked to experiment with integrating games in teaching grammar inductively. He finds this method is very stimulating, as "...it reduces the challenge of inductive learning in understanding the target structure and increases students' engagement while subconsciously learn grammar". Teacher A believes that his students had different level of English ability and games reduces this gap. Other teachers liked to exercise students' memorization on grammar rules while teaching grammar deductively. Thus, teacher $\mathrm{D}$ and $\mathrm{C}$ presented and explained the grammar rules to be memorized and assigned students to exemplify it through generating sentences based on the memorized rules. Teacher B also involved games in teaching grammar, especially when grammar points to be introduced is difficult "...it should be preceded with rules explanation which relies a lot on rules memorization".

\subsubsection{Motive}

The interview reveals that the observed teachers had different motives in teaching grammar. Inductive teaching was motivated by teachers' goal to enhance students' communicative ability. The class was 
designed so the students had as many chances as possible to do interaction. For the teachers who applied deductive approach their goal of teaching was to enable students to have immediate understanding. As stated by teacher B “...deductive method is easy to understand" Thus, they emphasized on understanding rules by dissecting grammar pattern to be recognized by the students. They also mentioned about how deductive approach as more effective to increase students recognition on rules, an ability which is essential for them to answer grammar-related test items.

\subsubsection{Experience and Knowledge}

The study provides evidence that teacher experience and knowledge indeed shape their teaching. Teacher A who had previous experience dealing with teaching grammar inductively preferred to use this approach more often. However, the other teachers who just ' $k n e w$ ' about inductive grammar but never experienced it (during their own learning grammar journey or by observing other teachers' teaching grammar inductively) preferred to apply deductive approach as it is more convenient. These teachers believed that inductive approach requires teachers to be more creative, more knowledgeable peers in terms of grammar teaching innovation and creativity is important as addressed by teacher C "Junior teachers can encourage the application of this innovation. It is because junior teachers seem to have more innovations which updated in accordance with the demands of the curriculum." They indicated that teachers who have little update in grammar teaching innovation were inclined to choose deductive approach, because as stated by Teacher B "Deductive approach is simple, convenient and time-efficient because teachers do not need to do much innovative strategy"

\subsubsection{Expectation}

Teacher A, who applied inductive approach had an expectation to follow educational development. He invested some time to learn about new strategy to teach grammar inductively. He had high expectation toward his students, i.e. to have the skills or competency as demanded by current communication demands. $\mathrm{He}$ stated that "...teachers who expect high toward students' outcome would apply a method which is considered as the best and of course in line with school standards." However, other teachers who were in favor of deductive approach had an expectation to help students reducing the burden of grammar learning. They facilitated their students with a quick, instant way of understanding grammar to enable them with their learning, i.e. answering grammar test correctly.

From this personal factors, it can be summarized that teachers may want to fulfill the current teaching demand, do the experiment with innovative teaching approach or maintain their practice in the convenient zone to help students reaching short-term goal, i.e. answering test. Teachers' personal factor, factors which come from their own selves, derives them to choose which grammar teaching approach suitable with their teaching attitude, interest, motive, experience/ knowledge, and expectation. For example, teacher B mentioned the reason of using deductive approach is due to his lack of knowledge and experience in conducting inductive approach. From this admission, it can be interpreted that teacher B is not ready to apply inductive approach. Readiness relates with competence and willingness to learn and use new skill [30]. This admission contradict the idea of professional development that is to keep updating their own knowledge as long as their career as teachers [31]. Teachers are not always eager to update their skills continuously, this phenomena is quite common. Saukah and Utami [32] mentioned that teachers' willingness to update their skills relates to their professional enthusiasm. A teacher who love and appreciate their work as teachersinclined to do efforts or pursue programs to improve their performance.

\subsection{Contextual Factors: what they can, what they do, what they want, what they feel}

\subsubsection{Student readiness}

All of the observed teachers perceived that neither approach is outrank the other and that both approaches had their own strengths and weaknesses. Teacher who conducted deductive grammar teaching perceived that actually inductive approach is good, but they preferred not to conduct it because as stated by teacher B "...to engage with inductive teaching students need to already 
develop sufficient English skills". Teacher A who was inclined to apply inductive approach stated that "sometimes due to students' very low ability, I go with deductive, because it introduces rules directly and consumes less time"

\subsubsection{Peers readiness}

Interaction among peers affects what teachers do in their class. Teacher A, as a junior teachers, found it challenging to do co-teaching with senior teachers who were in favor with deductive approach "As a junior, I have to do what they think the best. Then, I just go with combination of both deductive and inductive" What he meant by combining these approaches is taking a bit of the characteristics of each approach. He would start with few sentences to exemplify rules, asked students to analysis their differences or similarity, and then he would explained the grammatical pattern to clarify the concept.

\subsubsection{Level of grammar difficulty}

Grammar structure can be varied in terms of the levels of difficulty. The teachers mentioned that there are structures which are easier to learn such as auxiliary verbs and pronouns and there are also structures which are more challenging to learn such as phrasal verbs, tenses and preposition. For more difficult structures, the teachers selected deductive approach. Teacher $\mathrm{C}$ stated that "In Indonesian structure, we do not have verb changes to indicate time of action, which does not give advantage for our students to learn about tenses" As students can not reflect of their first language structure repertoire, changing of verbs structure needs to be explain explicitly. Their action to choose deductive for more difficult grammar structure is reasonable for deductive allows immediate understanding.

\subsubsection{Curriculum demand}

The teacher also considered curriculum demand in their grammar approach choice. Teachers were inclined to 'follow' the demand when they have to demonstrate their performance quality in a teaching assessment or during a routine supervision by the principal or supervisors. When they prompted with question about how they write their lesson plan, as admitted by teacher $\mathrm{D}$, they "Follow the demands of the curriculum as it has been determined by the school" Their daily practice may not always reflect these demonstration or administration.

\subsubsection{Student feeling}

Students feeling is considered a factor of choosing grammar teaching approach. All students like to learn through a way that they do not feel they are learning. Teacher A reported that "Inductive approach is more fun and allows students to have better engagement. Students become more active because they have to construct their learning". He perceived that students feeling is very important because it can encourage or discourage learning. Meanwhile, teacher B stated that his choice of deductive approach also because "students like when the rule is clear, they understand better"

Despite the curriculum demands of communicative instruction, both deductive and inductive teachers approved that traditional approach or deductive is still predominant in teaching grammar at the school. However, their choice always depends on how they weigh these factors.

The study shed a light on the inclination of grammar teaching decision which is hinged largely on contextual factors, especially student readiness and difficulty level of grammar material, than personal factor. For example, inductive teacher (Teacher A) reported that, despite his readiness to teach grammar deductively, he would readjust his choice to deductive when material is too difficult and students' ability is too low. Likewise, deductive teachers also tried to combine deductive approach with some games to maintain students' interest.

These teachers' action is reasonable, as stated by Siriwichai [33], teachers need to take into account student readiness because it is determined as student capability in understanding the instruction given by teacher. Toprak [24] also views that students' desire to follow classroom activity is essential to be noticed. Capability in learning as well as enthusiasm, positive learning attitude and willingness to participate is an indication of students' readiness [34]. Recent research and various studies [24], [35], [36] provide an evidence that student readiness affects learning development. It can be interpreted that ensuring student readiness is deemed necessary when implementing grammar teaching approach for better learning outcome. 
From the interview it is also known that the students at school mostly had lack of ability in understanding grammar through inductive approach. This finding is in line with the study conducted by Gorat and Prijambodo [20] about the effect of using deductive and inductive approach in teaching English. It was found that the major problem encountered by teacher in the application of inductive approach lies on students' ability.

Beside student readiness, what is interesting to be discussed is how senior co-teacher affects junior peer. Senior's grammar teaching preferences influences their junior's. This is interesting because during the interview more senior teachers expected junior teachers' innovation would bring changes in grammar teaching.

Table 3. Affecting factors summary

\begin{tabular}{|c|c|c|}
\hline Affecting Factors & Inductive teacher & Deductive teacher \\
\hline \multicolumn{3}{|l|}{ Personal factors } \\
\hline 1. Attitude & $\begin{array}{l}\text { Adjusting to current teaching } \\
\text { paradigm }\end{array}$ & Having a technical orientation \\
\hline 2. Interest & $\begin{array}{l}\text { Doing inductive innovatively to } \\
\text { reduce students gap }\end{array}$ & Doing deductive in a more fun way \\
\hline 3. Motive & $\begin{array}{l}\text { Enhancing students' communicative } \\
\text { ability. }\end{array}$ & $\begin{array}{l}\text { Enabling students' immediate } \\
\text { understanding }\end{array}$ \\
\hline $\begin{array}{l}\text { 4. Experience and } \\
\text { knowledge }\end{array}$ & $\begin{array}{l}\text { Having experience and knowledge } \\
\text { about inductive }\end{array}$ & $\begin{array}{l}\text { Having experience and knowledge } \\
\text { about deductive }\end{array}$ \\
\hline 5. Expectation & $\begin{array}{l}\text { Following educational development } \\
\text { and improving students } \\
\text { communicative ability }\end{array}$ & $\begin{array}{l}\text { Helping students to reduce the } \\
\text { burden of grammar learning }\end{array}$ \\
\hline \multicolumn{3}{|l|}{ Contextual factor } \\
\hline 1. Student readiness & $\begin{array}{l}\text { Applying inductive for High ability } \\
\text { students and deductive for } \\
\text { extremely low ability students }\end{array}$ & $\begin{array}{l}\text { Applying deductive mostly for any } \\
\text { level of ability }\end{array}$ \\
\hline 2. Peers readiness & $\begin{array}{l}\text { Grammar approach choice affected } \\
\text { by the senior peers in co-teaching } \\
\text { context. In individual teaching, he } \\
\text { followed inductive teaching }\end{array}$ & $\begin{array}{l}\text { Following deductive teaching in co- } \\
\text { teaching and individual teaching } \\
\text { context }\end{array}$ \\
\hline $\begin{array}{l}\text { 3. Level of grammar } \\
\text { difficulty. }\end{array}$ & $\begin{array}{l}\text { Mostly doing inductive for any } \\
\text { levels, but for extremely challenging } \\
\text { grammar concept, combination of } \\
\text { deductive and inductive is his } \\
\text { choice }\end{array}$ & Doing deductive mostly for any level \\
\hline 4. Curriculum demand & Following curriculum demand & $\begin{array}{l}\text { Following curriculum demand for } \\
\text { the sake of teaching assessment or } \\
\text { administration }\end{array}$ \\
\hline 5. Student feeling & $\begin{array}{l}\text { Choosing inductive for it is more fun } \\
\text { and enjoyable }\end{array}$ & $\begin{array}{l}\text { Choosing deductive for reducing } \\
\text { students anxiety and help } \\
\text { immediate grasp }\end{array}$ \\
\hline
\end{tabular}


However, junior teacher seemed to see that grammar teaching orientation were dictated by senior teachers. This finding implicates peer sharing between senior and junior need to be facilitated at schools. Study conducted by Haigh [37] mentioned that informal conversation between teachers can be a valuable professional sharing. Teachers should be adaptable and willing to learn from others through this professional sharing to improve their practices. Besides, school administrators need to encourage academic atmosphere at school to facilitate professional sharing. Many teachers do not want to share because school cultures dictates otherwise.

\section{CONCLUSION}

Teachers' decision on which grammar teaching approaches to use is affected by two factors, namely personal and contextual factors. However, the study found that their decision is affected more by contextual factors especially students readiness and grammar material difficulty, than by personal factor. This findings implicates that teacher considers student ability, students wish and feeling more in designing their teaching. Apparently, the participants of the study believed that their students' ability and how they want to learn grammar resonates to deductive approach. However, this interpretation is derived from teachers self-report, which can be merely justification for their action. Investigation on students' perspective is needed to assure how they actually want to learn grammar. The study also encourages awareness rising toward current 21 st century learning paradigm and professional development engagement.

\section{REFERENCES}

[1] J. Graus and P.-A. Coppen, Student teacher beliefs on grammar instruction, Lang. Teach. Res., 2015.

DOI: https://doi.org/10.1177/1362168815603237.

[2] J. C. Richards and W. A. Renandya, Methodology in Language Teaching, in: J. C. Richards, Proceedings fo Cambridge, University Press, 2002, pp. 1-405.

[3] J. Zhang, Necessity of Grammar Teaching, in: Proceedings of Int. Educ. Stud., vol. 2, 2009, pp. 184-187.

[4] M. M. Obeidat and M. A. Alomari, The Effect of Inductive and Deductive Teaching on EFL Undergraduates ' Achievement in Grammar at the Hashemite University in Jordan, in; Proceedings of Int. J. High. Educ., vol. 9, 2020, pp. 280-288. DOI: 10.5430/ijhe.v9n2p280.
[5] W. Decoo, The Induction-Deduction Opposition: 1 . Induction and deduction in a more theoretical educational framework, in: Proceedings of Int. Rev. Appl. Linguist., vol. 34, 1996, pp. 95-118.

[6] K. Sharandeep, D. R. Niwas, Introduction: Role of Grammar in English Language Methods of Teaching Grammar: - Review of Related Literature, in: Proceedings of Int. J. Adv. Res., vol. 4, 2016, pp. 1241-1247. DOI: https://doi.org/10.21474/IJAR01.

[7] C. Benitez-correa, P. Gonzalez-torres, and C. Ochoa-cueva, "A Comparison between Deductive and Inductive Approaches for Teaching EFL Grammar to High School Students, in: Proceedings of Int. J. Instr., vol. 12, 2019, pp. 225-236.

[8] E. Berendse, Effectiveness of Inductive and English Classroom in a L1 Dutch Environment, Bachelor Thesis English Lang, Cult. Utr. Univ., , 2012.

[9] S. Chalipa, The effect of inductive vs. deductive instructional approach in grammar learning of ESL learners, in: Proceedings of Int. Res., vol. 2, 2013, pp. 176-187.

[10] S. Arifin, Deductive and Inductive Methods in Teaching Tenses, vol. 1, 2016, pp. 73-90.

[11] I. K. T. Adi Ana and N. M. Ratminingsih, Teaching English Tenses to EFL Learners: Deductive or Inductive ?, in: Proceedings of Int. J. Cross-Disciplinary Subj. Educ., vol. 2, pp. 998-1004, 2012.

[12] S. Negahdaripour and A. Amirghassemi, "The Effect of Deductive vs . Inductive Grammar Instruction on Iranian EFL Learners' Spoken Accuracy and Fluency, Int. J. Appl. Linguist. English Lit., vol. 5, 2016. DOI 10.7575/aiac.ijalel.v.5n.1p.8.

[13] L. A. Rismayanti, A Case for Deductive Teachers' Perception using Inductive Instruction in Teaching English Grammar for Junior Students, in: Proceedings of J. Educ. Res. Eval., vol. 5, 2021, pp. 1-12.

[14] J. E. Rini, "The position of English Indonesia," Widya Mandala Cathol, Univ. Surabaya, vol. 2, 2014, pp. 20-37. 
[15] H. Hartoyo, in: Proceedings of Grammar in the teaching of EFL in Indonesia, Semarang, Pelita Insani, 2006.

[16] A. Paivio and I. Begg, in: Proceedings of Psychology of language, Englewood Cliffs, N.J.Prentice-Hall, 1981.

[17] M. Alhaysony, EFL Teachers and Learners Perceptions of Grammatical Difficulties, in: Proceedings of Adv. Lang. Lit. Stud., vol. 8, 2017, pp. 189-197. DOI: 10.7575/aiac.alls.v.8n.1p.188.

[18] M. Polat, Teachers' Attitudes towards Teaching English Grammar : A Scale Development Study, In: Proceedings of Int. J. Instr., vol. 10, 2017, pp. 379-398.

[19] O. Önalan, Non-Native English Teachers' Beliefs on Grammar Instruction, in: Proceedings of English Lang. Teach., vol. 11, 2018, doi: 10.5539/elt.v11n5p1.

[20] L. Gorat and V. L. Prijambodo, The Effect Of Using Deductive Approach And Inductive Approach In Teaching English To Students On Their Conditional, in: Proceedings of Magister Sci., 2013, pp. 78-92.

[21] M. A. Alzu'bi, Effectiveness of Inductive and Deductive Methods in Teaching Grammar, Adv. Lang. Lit. Stud., vol. 6, 2015. DOI: 10.7575/aiac.alls.v.6n.2p.187.

[22] K. Sharandeep and D. R. Niwas, Introduction: Role of Grammar in English Language Methods of Teaching Grammar: - Review of Related Literature, in: Proceedings of Int. J. Adv. Res., vol. 4, 2016, pp. 1241-1247.

[23] K. Sik, Tradition or Modernism in Grammar Teaching: Deductive vs. Inductive Approaches, in: Proceedings of Soc. Behav. Sci., vol. 197, 2015, pp. 2141-2144.

[24] T. E. Toprak, Teaching Grammar Is Not My Main Responsibility': Exploring Efl Teachers ' Beliefs About Grammar, in: Proceedings of Int. J. Educ. Teach., vol. 6, pp. 205-221, 2019.

[25] W. M. Trochim, Research Methods Knowledge Base, Atomic Dog Publishing, 2001.

[26] M. Q. Patton, Qualitative Evaluation and Research Methods, Thousand Oaks, CA Sage, 2015.
[27] S. P. Robbins, T. A. Judge, Organisational Behavior (15th ed.) Boston, Pearson, 2013.

[28] B. M. Miles and A. M. Huberman, An Expanded Sourcebook: Qualitative Data Analysis, London, Sage Publication, 1994.

[29] I. G. A. L. P. Utami and S. Prestridge, How English Teachers Learn In Indonesia: Tension Between Policy-Driven And Self- Driven Professional Development, in: Proceedings of TEFLIN J., vol. 29, 2018, pp. 245-265, 2018.

[30] N. Ibrahim, A. Adzara'ai, R. Sueb, S. F. Dalim, Trainee Teachers' Readiness Towards $21^{\text {st }}$ Century Teaching Practices, 2018, pp. 1-8, 2019.

[31] H. Mizell, Why Professional Development Matters, Oxford, Learning Forward, 2010.

[32] A. Saukah and I. G. A. L. P. Utami, Levels of Involvement in the English Teachers' CPD ( Continuous Professional Development ): The Degree of Professional Enthusiasm, in: Proceedings of J. Asia TEFL, vol. 14, 2017, pp. $336-345$

[33] C. Sriwichai, Students' Readiness and Problems in Learning English through Blended Learning Environment, in: Proceedings of Asian J. Educ. Train., vol. 6, 2020, pp. 23-34, DOI: 10.20448/journal.522.2020.61.23.34.

[34] L. Manasia, M. G. Ianos, and T. D. Chicioreanu, Pre-Service Teacher Preparedness for Fostering Education for Sustainable Development: An Empirical Analysis of Central Dimensions of Teaching Readiness, Sustain in: Proceedings of MDPI, Open Access J., vol. 12, 2020, pp. 1-24.

[35] L. Y. Xuan and A. B. Razali, Self-Directed Learning Readiness (Sdlr ) Among Foundation Students From High And Low Proficiency, in: Proceedings of Malaysian J. Learn. Instr., vol. 15, 2018, pp. 55-81.

[36] L. Chorrojprasert, Learner Readiness - Why and How Should They Be Ready?, Learn J. Lang. Educ. Acquis. Res. Netw. J., vol. 13, 2019, pp. 268-274.

[37] N. Haigh, Everyday Conversation as a Context for Professional Learning and Development," Int. J. Acad. Dev., vol. 10, 2005, pp. 3-16, DOI: 10.1080/13601440500099969. 